\title{
法制改正紹介
}

\section{都市再生特別措置法等の改正による 地域のまちづくりに対する支援強化について}

国土交通省都市・地域整備局

\section{1 施策の背景}

地方都市を中心にまちの魅力や活力の低下が急速に 進展している中, まちづくり会社やNPO等の新たな主 体が，地方公共団体とともにまちづくりを担っていく ことが強く期待されています。

また, 鉄道駅周辺や大規模な開発が行われた地域等 において, 地域のまちづくりルールに基づいて歩行者 デッキや歩行者専用通路等を整備・管理する事例が増 加しつつあります。

こうした中, 今般の都市再生特別措置法等の改正法 は, 地域の住民や地元企業等が主体となったまちづく り活動や公共的な空間の適切な整備・管理等を通じて, まちの魅力や活力の維持・向上を促進し, 地域の活性 化を図ることを目的として制定されたものです。

\section{2 施策の概要及び施行時期}

「都市再生特別措置法及び都市開発資金の貸付けに 関する法律の一部を改正する法律」によって, 地域の まちづくりに対する以下の支援措置が講じられること となりました。

(1)まちづくり会社等に対する資金支援の充実

(2)歩行者ネットワーク協定制度の創設

(3)まちづくり交付金の拡充 等

なお，本法は，本年 6 月 3 日に公布されました。本 法のうち予算に関係する部分は本年 9 月 1 日に, それ 以外の部分については本年10月 1 日に施行することと しております。

\section{3 まちづくり会社等に対する資金支援の 充実}

近年, まちづくり会社やNPO等の活動が活発化しつ つありますが, これらの主体は, 最近の経済情勢の悪 化等もあり，資金面で困難に直面していることが多い 状況です。

こうした状況を踏まえて，まちづくり会社等の民間 のまちづくり主体について，ハード事業に関する無利 子貸付制度やソフト的な活動に対する補助制度を創設 することとしました。

\section{(1) ハード事業に対する無利子貸付制度の創設}

まちの活性化のボトルネックとなっていることが多 い空き地・空き店舗の活用や集客力の強化を図るため の駐車場・駐輪場整備等に対して無利子貸付けを行う こととしています。

【無利子貸付制度の概要】

○対象者

・都市再生整備推進法人 (一般社団法人又は一般財 団法人であるものに限る。地方公共団体の出資は 不要。)

・まちづくり法人(地方公共団体が $1 / 4$ 以上を出資す る会社, 公社)

\section{○対象事業}

駐車場・駐輪場の整備, 空き地・空き店舗のリニュー アル・コンバージョン等

○貸付条件

全体事業費に対して, 国が $1 / 4$, 地方公共団体が $1 / 4$ を負担し, 合計 $1 / 2$ を地方公共団体経由で無利子貸付け を行う。

予算額

20 億円

○無利子貸付けのスキーム

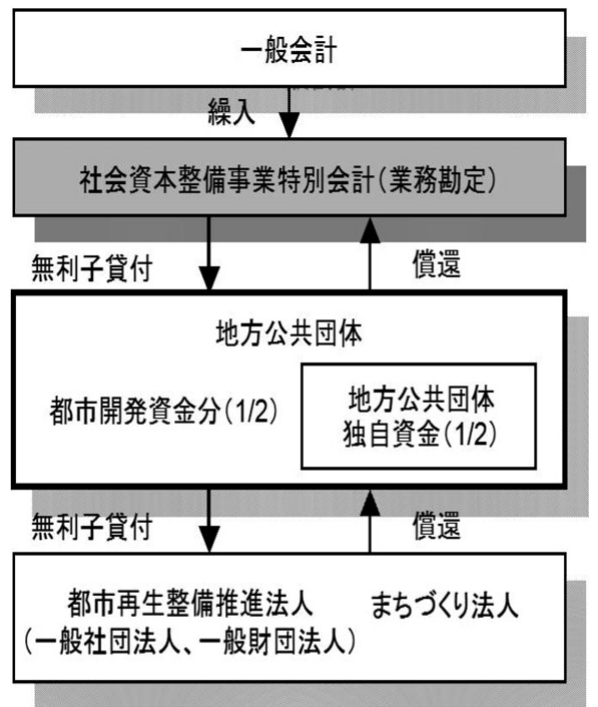




\section{(2) ソフト的な活動に対する補助制度 (都市環境改善支} 援事業) の創設

民間のまちづくりの担い手による地区レベルの活動 を促進するため, まちづくり組織の立ち上げ等に関す るコーディネート業務, 都市環境の維持・改善に資す る計画の作成, オープンカフェ等の社会実験・実証事 業等に対する補助制度として, 都市環境改善支援事業 (エリアマネジメント支援事業)を創設しました。

【都市環境改善支援事業（エリアマネジメント支援事 業) の概要】

○対象者

地方公共団体, 中心市街地活性化協議会, 景観協議 会, 民間事業者等

○対象事業

・計画コーディネート(組織の立ち上げ計画の立案・ 調整等)

・都市環境維持 - 改善計画作成

・社会実験・実証事業等（にぎわい創出のための オープンカフェの設置, 屋外広告物の高質化等)

補助率

·地方公共団体, 協議会施行は $1 / 2$ の直接補助

· 民間事業者等施行は国 $1 / 3$, 地方公共団体 $1 / 3$ の間 接補助

予算額

国費 1.5 億円

事業費 3.4 億円

\section{4 歩行者ネットワーク協定の創設}

\section{(1) 制度趣旨}

鉄道駅周辺や大規模な開発が行われた地域, 中心市 街地等に拈いて, 歩行者デッキや地下通路, 歩行者専 用通路等を公的主体のみならず個人や企業等の地権者 が所有する事例が増加しており，こうした公共的な空 間の適切な整備や管理に対するニーズが高まっていま す。

こうした状況を踏まえて, 歩行者デッキや地下通路 等の公共的な空間について, 地域の地権者等による適 切な整備, 管理を推進し, 都市の居住者や滞在者等の 利便性及び安全性の向上を通じてまちの魅力や活力を 高めるため, 都市再生緊急整備地域や都市再生整備計 画区域内の一団の土地の所有者等による歩行者ネット ワーク協定制度を創設しました。

【歩行者ネットワーク協定の概要】

○概要

・歩行者の移動上の利便性・安全性の向上のための 経路（歩行者デッキ, 地下通路, 歩行者専用通路 等）の整備・管理について, 土地所有者等が全員 合意により締結する協定。
・市町村長が認可。

○区域

・都市再生緊急整備地域（65地域 6,612ha）

・都市再生整備計画区域（=まちづくり交付金の区 域：1,276地区）のうち，一定の要件をみたすもの として, 同計画に記載された区域。

○内容 $\rightarrow$ 承継効で担保

・管理費用の適正な分担

・ベンチ, 植栽, エスカレーター等の設置管理

·広告物の設置・管理

・清掃・防犯活動

・歩行者経路 (デッキ, 地下通路等)の整備・存続等

\section{(2) 歩行者ネットワーク協定の法的な意義}

歩行者デッキや地下通路等については民間の地権者 や道路管理者等の行政主体等の間で任意の協定が締結 されることが通常ですが, こうした任意の協定は, 経 営破綻等に伴って地権者が入れ替わってしまった場合， その後に地権者となった者にはその効力が及ばないこ ととなります。

そこで，こうした任意の協定を法律上位置づけ，市 町村長の認可にかからしめることによって, 新たに地 権者となる者にも当該協定の効力が及ぶこととなる, いわゆる承継効を付与することといたしました。

\section{(3) 地権者のメリット}

任意の協定にはない承継効が付与されることで, 適 正な費用負担の下で公共的な空間を適切に整備・管理 するための地域のまちづくりルールが, 第三者が土地 等を取得して地域に入ってきた場合にも適用されるこ ととなり安定的・継続的なまちづくりが可能となりま す。

\section{5 まちづくり交付金の拡充}

まちづくり交付金は, 地方の自主性・裁量性を活か しながら全国の都市再生を推進する制度であり, 平成 21年度では全国748市町村, 1,276地区で活用されてい ます。

一方で, 中心市街地活性化法の改正や歴史まちづく り法の制定, 環境モデル都市の指定などを背景に, 国 としてより一層推進すべき施策の実現においても，ま ちづくり交付金のより一層の支援が期待されていると ころです。

このようなことから, 平成 21 年度の制度改正により， 中心市街地の活性化, 歴史まちづくり, 低炭素型まち づくり等，国として特に推進すべき施策に関連した都 市再生の円滑かつ迅速な推進を図るため, これら施策 に関連する一定の要件を満たす地区については，まち づくり交付金の交付率上限を現行 $40 \%$ から $45 \%$ に拡充 し，支援を強化することとしています。 